\title{
How to remedy Eurocentrism in IR? A complement and a challenge for The Global Transformation
}

\author{
PINAR BILGIN \\ Department of International Relations, Bilkent University, Ankara, Turkey \\ E-mail: pbilgin@bilkent.edu.tr
}

\begin{abstract}
While IR's Eurocentric limits are usually acknowledged, what those limits mean for theorizing about the international is seldom clarified. In The Global Transformation, Buzan and Lawson offer a 'composite approach' that goes some way towards addressing IR's Eurocentrism, challenging existing myths about the emergence and evolution of the international system and society. This paper seeks to push the contribution made by Buzan and Lawson in two further directions: first, by underscoring the need to adopt a deeper understanding of Eurocentrism; and second, by highlighting how this understanding helps us recognize what is missing from IR theorizing - conceptions of the international by 'others' who also constitute the international. I illustrate this point by focussing on a landmark text on Ottoman history, Ortaylı's The Longest Century of the Empire.
\end{abstract}

The Global Transformation (TGT) (Buzan and Lawson 2015) offers a 'composite approach' to studying world history that understands modernity not in terms of factors endogenous to 'Europe' but as a product of the 'uneven and combined' dynamics of the long 19th century. Re-stated in Said's $(1975,1993)$ terms, the 'composite approach' constitutes an effort to study world history by focussing on the multiple 'beginnings' of the 'global transformation', as opposed to searching for particular 'origins' or 'originalities' in 'Europe' or elsewhere. As the contributions to this symposium have also highlighted (albeit in different ways) IR has a long way to go in coming to terms with its own 'Eurocentrism'. Against this background, the promise of Buzan and Lawson's framework becomes more apparent for those who specialize in 'non-European' parts of the globe and who are contributing to the project of rendering IR less Eurocentric.

My aim in this paper is to illustrate how Buzan and Lawson's 'composite approach' could be utilized for rendering IR less Eurocentric by focussing on a text on Ottoman history by the renowned historian Ortaylı (1983). Entitled The Longest Century of the Empire, Ortaylı's text looks at the 
19th century from the perspective of the Ottoman Empire, focussing on the Ottoman leaders' perspectives on modernity and their experiences with modernization in different parts of the Empire. In so doing, Ortaylı argues against those accounts that conflate Ottoman modernization with the Empire's entry into the international society and/or 'Westernization'. Modernization and especially reform in the Ottoman Empire has a long history that was shaped by interactions between various parts of the Empire and the rest of the world. It was only in the 18th century that permanent Ottoman Embassies were established in several European capitals (Burçak 2007). The formal recognition of the Ottoman Empire as a member of international society came in 1856 . Notwithstanding the presence, since the mid-to-late 19th century, of individual Ottoman leaders who called for Westernization as a solution to the Empire's decline, the process of Westernization did not begin in earnest until the declaration of the Republic of Turkey in 1923.

Bringing in the Ottoman experience, I suggest, both complements and challenges Buzan and Lawson's approach. The complementary aspect is in the way in which the Ottoman experience, as told by Ortayl, reinforces the authors' point about the need for a 'composite approach' to studying world history. The challenge is about the Ottomans' conceptions of the international. For the 19th century transformation in the ideational structure of the international society (as highlighted in TGT) cannot be fully captured without inquiring into new or non-members' conceptions of the international. Such an understanding underscores the need for exploring the ideas of those who constitute international thought about the international. As such, I distinguish between tracing 'European' origins of thinking about the social and international (see the contribution to this symposium by Patricia Owens) and emphasize studying the international as a social space co-constituted by 'others' who also had ideas about the international (see e.g. Grovogui 2006; Jabri 2014).

\section{Why seek to remedy Eurocentrism in IR?}

Rendering IR less Eurocentric has turned out to be a more challenging task than initially imagined. While IR scholars have, since the mid-1980s, sought to integrate differently situated approaches (i.e. from outside Western Europe and North America) into the discipline, IR's Eurocentrism has persisted. Arguably, this is because the constitutive effects of Eurocentrism have not always been attended to (Barkawi and Laffey 2006). But then, the constitutive effects of Eurocentrism are difficult to address, for as highlighted by Reus-Smit in his contribution to this symposium, 
while theory builds on history, history is read through theory. Put differently, addressing the Eurocentric limits of IR involves addressing the Eurocentric historical accounts that students of IR draw upon. The need to underscore the fluid, undetermined and intertwined character of world history is also one of the reasons why Buzan and Lawson engaged in writing a history of the 'global transformation'. ${ }^{1}$ Existing accounts, many of which read contemporary ('standard') concepts back into history end up reinforcing Eurocentrism in IR.

Two different understandings of Eurocentrism can be found in the IR literature. The first views Eurocentrism as an 'erroneous' approach to world history. Being Eurocentric in IR is understood as building upon 'erroneous' accounts that put 'Europe' at the centre of history regardless of whether 'Europe' had (yet) become central to world politics or not. The second understanding approaches Eurocentrism as a 'consciousness' that has allowed erroneous accounts to prevail notwithstanding the availability of non-Eurocentric historical accounts (Amin 2009 [1989]). Depending on which conception of Eurocentrism we adopt, Eurocentrism comes across as less or more of a challenge for IR.

Buzan and Little (2002) built upon understandings of Eurocentrism as 'world history centred on Europe' in their appraisal of IR scholarship. Particularly problematic, Buzan and Little argued, were those aspects of IR scholarship that put Europe at the centre when studying periods of world history when Europe was not (yet) at the centre. As such, Buzan and Little offered an important corrective to IR scholarship that drew upon Eurocentric accounts of world history. What rendered their critique partial was the implication of their argument - that putting Europe at the centre of one's research may not necessarily be a problem when looking at those periods of world history when European powers did play central roles in shaping world politics. In contrast, Grovogui (2006) maintained that Eurocentrism should not be viewed as a problem that only emerges when looking at those periods prior to Europe's ascent. This is because, argued Hobson (2009), Eurocentrism imposed limitations on research when studying periods of European ascent as well as the years prior to such ascent. Hence, the need to go beyond an understanding of Eurocentrism as 'world history centred on Europe'.

'Eurocentrism as consciousness' draws on Amin's $(1989,154)$ understanding of Eurocentrism as 'a theory of world history and, departing from it, a global political project'. This is what Reus-Smit refers to as

${ }^{1}$ Also see the burgeoning literature on 'uneven and combined development' discussed by Anievas in his contribution to this symposium. 
'deep Eurocentrism' in the opening essay of this symposium. According to Amin, 'Eurocentrism as consciousness' came about during the Renaissance and especially the age of Enlightenment, as 'Europe' sought to make a break with the past pattern of seeking foundations for knowledge in religion, looking instead for an anchor in 'science'. As Bernal (1987) and Mignolo (2003) have argued (in different ways), 'Europe's understanding of its own history was re-drafted during this period by drawing an almost straight line from Ancient Greece to modern 'Europe', thereby entrenching a Eurocentric account of world history that understood 'Europe' to have developed autonomously, almost without incurring any debts to 'others'.

Understanding Eurocentrism as 'consciousness' reminds us that being less Eurocentric is not as easy as looking at the histories of 'non-European' peoples. Eurocentrism as consciousness has shaped the history of both 'Europe' and the rest of the world. Furthermore, it is through the concepts developed in/by 'Europe' that students of IR make sense of world history. It is in this sense that Wallerstein (1997) termed as 'anti-Eurocentric Eurocentrism' the efforts of those who seek to point to progress and modernization outside 'Europe' while remaining within these same conceptual grids. Understanding Eurocentrism as consciousness, then, helps to underscore how it is not merely our understanding of world history or the histories of 'non-European' peoples that suffer from the limitations of Eurocentrism. Eurocentrism has constituted a limitation for IR regardless of whether the story being told is about 'Europe' or other parts of the world, or whether 'Europe' at the time was 'central' to world politics or not.

\section{The need for a 'composite approach': studying 'beginnings'}

One of the contributions of TGT is drawing on different historical accounts and bringing them together through adopting a 'composite approach' to studying world history. In doing so, Buzan and Lawson distinguish their approach to world history from Hobson's (2004) search for The Eastern Origins of the Western Civilization. Hobson's study sought to counter Eurocentrism by (1) pointing to the 'Eastern' origins of what are often portrayed as 'Western' achievements; and (2) identifying the ways in which learning between the 'East' and the 'West' was not unidirectional but mutual. Buzan and Lawson's 'composite approach', in contrast, points to the multiple sources of 'global modernity'. As such, Buzan and Lawson's approach to world history could be viewed as having affinities with Said's preferred approach to studying 'beginnings', and not searching for 'origins' or 'originalities' (be it 'Eastern' or 'Western'). 
In Beginnings: Intention and Method, Said (1975) sought to adopt 'beginnings as method'. Whereas studying origins and originalities implied singular sources for ideas, studying beginnings acknowledged multiple sources for ideas, and focussed on the process of learning from one another in their development (Said 1975, 1993). For Said (1993, 217), the multiplicity of beginnings served as the basic condition of humankind:

A confused and limiting notion of priority allows that only the original proponents of an idea can understand and use it. But the history of all cultures is the history of cultural borrowings. Cultures are not impermeable; just as Western science borrowed from Arabs, they had borrowed from India and Greece. Culture is never just a matter of ownership, of borrowing and lending with absolute debtors and creditors, but rather of appropriations, common experiences, and interdependencies of all kinds among different cultures. This is a universal norm.

Said's emphasis on the need to make sense of 'the connections between things' helps to address Eurocentrism in both senses of the term. For example, Said's 1978 book Orientalism inquires into the Eurocentric limitations of Oriental Studies ('Eurocentrism as world history centred on Europe') and the ways in which students of Oriental Studies remained oblivious to those limitations ('Eurocentrism as consciousness') (cf. Amin 1989; Hobson 2012). Understood in the context of the study of IR, Said's approach to 'beginnings as method' highlights the need for studying the international through drawing upon 'contrapuntal readings' that highlight 'overlapping and intertwined histories'.

Over the years, Said's call for studying 'beginnings' and 'the connections between things' found resonance in the writings of the political theorist Buck-Morss (2009) on 'universal history', the historian Subrahmanyam (1997) on 'connected histories', and the sociologist Bhambra (2007) on 'connected sociologies'. Buzan and Lawson's 'composite approach' (as with Reus-Smit's insistence that choosing one origin or another as a 'political act') could be viewed as a step in this direction insofar as the authors have produced an account of the history of the 19th century through focussing on the multiple 'beginnings' of the 'global transformation' as opposed to searching for 'origins' or 'originalities' in 'Europe' or elsewhere.

\section{The longest century of the Ottoman Empire}

This and the following sections of the paper seek to illustrate how Buzan and Lawson's framework could be utilized for rendering IR less Eurocentric by focussing on Ortaylı's (1983) The Longest Century of the Empire. Ortayll's threefold focus on the Ottoman leaders' perspectives on 
modernity in 'Europe', intertwined experiences of modernity in different parts of the Empire and elsewhere in the world, and the ways in which the Ottoman leaders sought to respond to the 'rise' of 'Europe' and 'decline' of the Empire highlights the need for studying modernity as a product of the 'global transformation' of the 19th century.

According to Ortayl, Ottoman modernization cannot be reduced to encounters with the 'West' as a notion, or the Empire's formal entry into international society in 1856 . This is not only because the term 'Westernization' did not enter the vocabulary of Ottoman leadership until the mid-to-late 19th century. More importantly, Ortaylı argues, it is because modernizing dynamics can be located in different parts of the Empire, and in different ways well before the 19th century. Ortayl acknowledges that the Ottoman Empire was late to modernize its army and bureaucracy compared with some of its European counterparts, including Russia. Yet, he also notes that temporal differences need not be translated into a modernist hierarchy between those who 'lead' and others who 'follow'. Ortayli points to the economic, social, and political dynamics in the Empire that were separate from, but related to, dynamics in other parts of the world. Others such as Mitchell (2000) and Blumi (2011) have also pointed to the beginnings of modernity in the peripheries of the Empire that were separate from, but also connected to, dynamics at the imperial core.

Bringing in the Ottoman perspective on modernity as told by Ortayl complements Buzan and Lawson's framework insofar as this account reinforces the authors' point about the need for a 'composite approach' to studying world history. In particular, Ortayli's account of the Ottoman experiences of modernization points to the need to inquire into the multiple beginnings of modernity as opposed to assuming a unidirectional (from the 'West' to the 'rest') trajectory. Accordingly, Ortaylı's account also challenges the 'multiple modernities' scholarship that presumes peoples' disparate experiences with modernity in different parts of the world. ${ }^{2}$

\section{The challenge: the international through the eyes of 'Others'}

If the section above highlights points of complementarity between TGT and Ortaylı's account of Ottoman modernity, his account also presents a challenge for Buzan and Lawson. The challenge concerns the relative absence from TGT of others' conceptions of the international.

Ortayl does not explicitly discuss Ottoman conceptions of the international. His account focusses on the ways in which Ottoman leaders' view

2 On 'multiple modernities' see Phillips (2016); cf. Mignolo and Tlostanova (2006). 
of the Empire, 'Europe', and the Empire vis-à-vis 'Europe' underwent a transformation during the 19th century. However, one can tease out from his account a re-shaping of the Ottoman conception of the international during this period. These changes were taking place in the context of the Ottoman encounter with international society.

At the risk of oversimplification, it is worth highlighting that at the high point of Empire, the Ottoman notion of the international rested on a hierarchical view of the world that was legitimized by a Muslim cosmology, which placed the Ottomans at the top of the hierarchy as the protector of Dâr-ül İslâm (abode of Islam). While this cosmology did not demand war with non-Muslims, it nevertheless placed other world powers on lower pedestals in relation to the Ottoman self - as evinced by the reception of 'European' dignitaries in İstanbul (Yurdusev 2003). However, this hierarchical view of the world, and its leaders' 'equation of foreign policy with military adventure was ... contingent upon Ottoman military superiority' (Abou-El-Haj 2003). From the late 17th century onwards, as the Empire experienced one battlefield loss after another, the Ottomans found it increasingly difficult to hold onto such a hierarchical view of world politics (Deringil 1998).

Ortayli's account highlights the degree to which the Ottoman leaders' view of the Empire, 'Europe' and the Empire vis-à-vis 'Europe' had changed by the beginning of the 19th century. During the 'longest century of the Empire', Ottoman leaders were responding not only to the decline in their military power, but also to perceptions of this decline in their status vis-à-vis European great powers, as evinced by the less-than-stellar treatment that Ottoman ambassadors received in some European capitals (Abou-El-Haj 2003).

The debates surrounding the decline and fall of the Ottoman Empire had left the Ottoman leadership divided as to how to reform the Empire (Aksan 1993). Resisting the simplified categories of 'modernizers' vs. 'conservatives', which cannot capture the complexity of Ottoman dynamics, Ortaylı maintains that Ottoman leaders of this period were a heterogeneous group united in their efforts to reform various institutions of the Empire. Indeed, the author insists that the Ottoman leaders housed both kinds of instincts ('modernizer' and 'conservative'), and that they did not make up their minds about the project of modernity, or the question of what kind of modernization efforts were to be pursued by the Empire.

In offering this argument, Ortayl acknowledges the significance of encounters with European great powers as the context for the emergence of Ottoman leaders' self-understandings about needing to prove the Empire to be a 'reformed' and 'civilized' state. He also acknowledges the importance of various attempts by European great powers to intervene in the affairs of the 
Empire as shaping the self-understandings of the Ottoman leaders. Ortayl, nevertheless, underscores the agency of the reformist leaders of the Empire, who either believed in the project of modernity or embraced modernization in a utilitarian manner as a form of survival in the face of an international society that was unwelcoming to the Ottoman Empire even as it accepted it as a formal member. Their policies vis-à-vis international society, notes Ortayl, were designed to minimize great power intervention in the affairs of the Empire and to make room for military and economic recovery.

Ortaylı's analysis of the Ottoman leaders' perspectives on modernity thereby constitutes a challenge for Buzan and Lawson's framework by highlighting the need to inquire into others' conceptions of the international when studying how international society changed during the 19th century. This is partly because dynamics of international society cannot be captured without paying attention to its relations with new and non-members. As Neumann has argued, the expansion of the international society needs reconceptualizing 'from being a question of expansion to being a relational question of the entrant going from one system to another' $(2011,483)$. That said, so far, there is little agreement as to the need for, and the methods of, accessing others' perspectives. ${ }^{3}$ I have suggested that IR's limitations cannot be addressed merely by 'adding on' others' perspectives as if the ideas and institutions of humankind in X or Y parts of the world evolved autonomously. The Ottoman leaders' conceptions of the international and their practices of diplomacy were shaped by, even as they responded to, their multiple interactions with international society.

\section{Conclusion}

Through focussing on Ortayli's study of the Ottoman Empire, I have sought to draw out the implications of Buzan and Lawson's 'composite approach' for addressing IR's Eurocentric limitations. This 'composite approach' allows us to inquire not only into the dynamics that shaped the relations between 'weak' and 'strong' (Barkawi and Laffey 2006) during the 19th century, but also the self-understandings of new or non-members vis-à-vis international society. Inquiring into the international as viewed from the perspective of 'others' would allow further insights into the ideational structure underpinning international society. The elements of such insights

\footnotetext{
${ }^{3}$ See, for example, the contributions to this symposium by Musgrave and Nexon, and Braumoeller, cf. Phillips. Arguably, suggesting the absence of a particular type of explanation before the 19th century (Owens) or calling for 'exotic international relations' (Musgrave and Nexon 2016, authors' emphasis) is only rendered possible by a discipline that overlooks the very contributions of those who were previously considered 'exotic'.
} 
may be available in 'micro histories' (Shilliam 2008), but they have not yet been brought to bear on macro-studies such as TGT.

The broader consequence of this argument is that IR's (Eurocentric) limitations have been constituted by (and constitutive of) the way research agendas are shaped, by overlooking others' conceptions of the international (Bilgin 2016). Incorporating others' conceptions of the international is not about adding on their perspectives to existing schemas, but inquiring into the constitutive relationships between the 'weak' and the 'strong', and locating in these relationships the multiple beginnings of the ideas and institutions of humankind.

\section{References}

Abou-El-Haj, Rifaat Ali. 2003. “Ottoman Diplomacy at Karlowitz.” In Ottoman Diplomacy: Conventional or Unconventional?, edited by Nuri Yurdusev, 89-113. New York: Palgrave Macmillan.

Aksan, Virginia H. 1993. "Ottoman Political Writing, 1768-1808." International Journal of Middle East Studies 25(1):53-69.

Amin, Samir. 2009 [1989]. Eurocentrism, Translated by Russell Moore and James Membrez. New York: Monthly Review Press.

Barkawi, Tarak, and Mark Laffey. 2006. "The postcolonial moment in security studies.” Review of International Studies 32(2):329-52.

Bernal, Martin. 1987. Black Athena: The Afroasiatic Roots of Classical Civilization. New Brunswick, NJ: Rutgers University Press.

Bilgin, Pinar. 2016. The International in Security, Security in the International. London: Routledge.

Bhambra, Gurminder K. 2007. Rethinking Modernity: Postcolonialism and the Sociological Imagination. New York: Palgrave.

Blumi, Isa. 2011. Foundations of Modernity: Human Agency and the Imperial State, vol. 9. London: Routledge.

Buck-Morss, Susan. 2009. Hegel, Haiti, and Universal History. Pittsburgh, PA: University of Pittsburgh Press.

Burçak, Berrak. 2007. "The Institution of the Ottoman Embassy and Eighteenth-Century Ottoman History: An Alternative to Göçek.” In Identity and Identity Formation in the Ottoman World: A Volume of Essays in Honor of Norman Itzkowitz, edited by Baki Tezcan, and Karl K. Barbir, 147-51. Madison, WI: University of Wisconsin Press.

Buzan, Barry, and George Lawson. 2015. The Global Transformation: History, Modernity and the Making of International Relations. Cambridge: Cambridge University Press.

Buzan, Barry, and Richard Little. 2002. "International Systems in World History: Remaking the Study of International Relations.” In Historical Sociology of International Relations, edited by Steve Hobden, and John M. Hobson, 200-220. Cambridge: Cambridge University Press.

Deringil, Selim. 1998. The Well-Protected Domains: Ideology and the Legitimation of Power in the Ottoman Empire, 1876-1909. London: I.B. Tauris.

Grovogui, Siba N. 2006. Beyond Eurocentrism and Anarchy: Memories of International Order and Institutions. New York: Palgrave Macmillan. 
Hobson, John M. 2004. The Eastern Origins of Western Civilization. Cambridge, UK and New York: Cambridge University Press.

Hobson, John M. 2009. "The Myth of the Clash of Civilizations in Dialogical-Historical Context." In Global Security, in Encyclopedia of Life Support Systems (EOLSS), edited by Pinar Bilgin, and Paul D Williams. Oxford: UNESCO, EoLSS Publishers.

Hobson, John M. 2012. The Eurocentric Conception of World Politics: Western International Theory, 1760-2010. New York: Cambridge University Press.

Jabri, Vivienne. 2014. "Disarming norms: postcolonial agency and the constitution of the international." International Theory 6(2):372-90.

Mignolo, Walter. 2003. The Darker Side of the Renaissance: Literacy, Territoriality, and Colonization. Ann Arbor, MI: University of Michigan Press.

Mignolo, Walter D., and Madina V. Tlostanova. 2006. "Theorizing From the Borders Shifting to Geo-and Body-Politics of Knowledge.” European Journal of Social Theory 9(2):205-21.

Mitchell, Timothy. 2000. Questions of Modernity, Contradictions of Modernity. Minneapolis, MN: University of Minnesota Press.

Musgrave, Paul, and Daniel Nexon. 2016. "The Global Transformation: More than Meets the Eye." International Theory 8(3):436-47.

Neumann, Iver B. 2011. "Entry Into International Society Reconceptualised: The Case of Russia." Review of International Studies 37(2):463-84.

Ortaylı, İlber. 1983. Imparatorluğun En Uzun Yüzyıl (The Longest Century of the Empire). İstanbul: Hil Yayınları.

Phillips, Andrew. 2016. "The Global Transformation, Multiple Early Modernities and International Systems Change." International Theory 8(3):481-91.

Said, Edward W. 1975. Beginnings: Intention and Method. New York: Basic Books.

Said, Edward W. 1993. Culture and Imperialism. New York: Knopf.

Shilliam, Robbie. 2008. "What the Haitian Revolution Might Tell us About Development, Security, and the Politics of Race." Comparative Studies in Society and History 50(3):778-808.

Subrahmanyam, Sanjay. 1997. "Connected Histories: Notes Toward a Reconfiguration of Early Modern Eurasia.” Modern Asian Studies 31(3):735-62.

Wallerstein, Immanuel. 1997. "Eurocentrism and its Avatars: The Dilemmas of Social Science." New Left Review (I/226):93-108.

Yurdusev, Nuri. ed. 2003. Ottoman Diplomacy: Conventional or Unconventional? New York: Palgrave Macmillan. 